\title{
Türk Postmodern Anlatılarında Modernizm Eleştirisi Üzerine
}

İsmail TURAN*

Birçok hakemli ve uluslararası dergilerde rastladığımız Dr. Gaye Belkız Yeter Şahin, Yeni Türk Şiirinde Tasfiye Hareketleri ve lisans ve yüksek lisans hocalarından olan Prof. Dr. Selçuk Çıkla ile hazırladığı 1839-1928 Arasında Basılmış Türkçe Şiir Kitapları Bibliyografyası adlı çalışmasından sonra doktora tezi olan bu çalışmasını bilim dünyasına sunmuştur. Ayrıca Hülya Argunşah'ın editörlüğünü yaptığı Sessizliğin Gölgesinde Hasan Ali Toptaş adlı çalışmada da bölüm yazarlığı yapmıștır.

Bilge Kültür Sanat Yayınları'ndan çıkan bu kitap, üç ana bölüm ve ek olarak belirtilen metin tahlillerinden oluşmaktadır. İlk bölümde modernitenin öncesinden hareket ederek modern dönemi ve kavram olarak modernizmi, ardından da postmodernizmi ele alarak incelemektedir. İlk bölümde edebî eserlerdeki yansımalarını da ele alan Şahin, "postmodernistlerin avangart bir tutumla modernizmin getirdiği şeylere mesafeli tutumlarıyla dikkatleri çektiğini” belirtmektedir. Postmodernizmin ne olduğu sorusuna verilen cevapların birbirinden farklı ve kavramla alakalı belirsizliklerin oluğuna dikkatleri çekerken nihayetinde postmodernizmi "modernizmden kopma ve kırılma” olarak değerlendirmektedir.

$\mathrm{Bu}$ eserin bilim dünyasına sunuluş amacı, bize göre edebiyatımızdaki postmodern anlatılarının kendilerinden önce zuhur eden modernizmin eksik, hatalı ve yanlış yorumlanmış olduğunu ve genel ihtiyatla eleştirel eserler oluşturulduğunu göstermek içindir.

\footnotetext{
* Kırklareli Üniversitesi Türk Dili ve Edebiyatı yüksek lisans öğrencisi. Kırklareli, Türkiye Elmek: turan.ismail.tde@gmail.com https://orcid.org/0003-4622-4301
} 
"Roman ve Eleştiri: Klasik ve Modern Romanlar ile Postmodern Anlat1larda Eleştirinin İşlevleri” üst başlığıyla ikinci bölümde yazar, romanın ilk ortaya çıkışını ve bu kavram hakkında farklı görüşlerin olduğunu, bazı araştırmacıların modern romanın ilk örneğini Decameron, bazılarının da Don Kişot olarak değerlendirdiğini belirtmektedir. Fakat bu eserleri romanın ilk örneği olarak sayan Batılı araştırmacıların bu görüşüne karşılık, 12. yy' da İbn Tufeyl'in yazdığ Hayy Bin Yakzan'ın da ilk roman örneği olarak görüldüğüne değinmektedir.

Edebî türlerdeki eleştirilere değinen yazar, birçok araştırmacının edebî eserlerdeki eleştirel tutumlarına, Don Kişot, Dönüşüm, Dava, Şato, Koku, Dövüş Kulübü gibi romanların toplumsal eleştirilerine, yazarların Türk klasiklerindeki yanlış Batılılaşmayı sorgulayıcı tutumlarına ve toplumun aksayan yönlerine dair yaptıkları eleştirilerine, postmodernizme geçiş sürecinde Türk yazarlarının oluşturduğu edebî metinlerdeki eleştirilere yer vermektedir.

Kitaba adının da verildiği üçüncü bölümde, Tanrı merkezli bakış açısından uzaklaşan bireyin zamanla maneviyatı arka plana bırakıp pozitivist bir bakış açısıyla aklın gücüne inanmaya başladığı ifade edilmektedir. Aydınlanmaya ve modern bilime, modern hayat şekillerine ve toplumsal meselelere, modern ekonomik sistemlere ve siyasi meselelere yönelik eleştirilere yer veren yazar, Türk yazarların (Adalet Ağaoğlu, Oğuz Atay, Metin Kaçan, Buket Uzuner, İhsan Oktay Anar vb.) eserlerinden örneklerle hacimli ve bir o kadar da nitelikli bir çalışma yaptı̆̆ını okurlara göstermektedir.

“Ekler” bölümünde ise, Latife Tekin'in Berci Kristin Çöp Masalları ve Buket Uzuner'in Balık İzlerinin Sesi adlı eserlerini olay örgüsü, zaman, mekân, şahıs kadrosu, tema, bakış açısı, anlatıcı, metinlerarasılık, üstkurmaca ve dil ve anlatım açısından tahlil etmektedir.

Bir bütün olarak esere bakıldığında Gaye Belkız Yeter Şahin'in otuzdan fazla edebî eseri okuyup ardından onlarla ilgili yaptığı yorumlara ve birçok araştırmacının alıntılarına şahit oluyoruz. Eseri okumaya başladığımızda bu çalışmanın ne kadar da emek ürünü olduğunu, takdir edilmesi gerektiğini düşünürüz. Dileriz bu gibi eserler bilim dünyasına kazandırılmaya devam edilir. 